\title{
Automotive Global Value Chains in Europe
}

\author{
Matteo Gaddi* and Nadia Garbellini**
}

\author{
Working Paper No. 160
}

August 23, 2021

\begin{abstract}
In this paper we examine the main transformations that are affecting European automotive industry and which challenges, in particular due to the transition to new forms of propulsion, the industry is going to face. The automotive industry is central to the European economy and the nature of the Global Value Chains are rapidly shifting. While individual countries have developed economic plans to address this, a broader EU wide plan is critically important to addressing the employment and environmental effects of these shifts.
\end{abstract}

https://doi.org/10.36687/inetwp160

JEL codes: L23, L24, L52, L62, L9, L98, R11

Keywords: Automotive Industry, Global Value Chains, European Industrial Policy

\footnotetext{
* Fondazione Claudio Sabattini

** Università di Modena e Reggio Emilia. ngarbell@unimore.it
} 


\section{Introduction}

The automotive sector is central for Europe: according to Eurostat data elaborated by ACEA (2020), it employs almost 2.7 million people in the manufacturing stages (final assembly, production of bodywork and parts and accessories), and 8.4 million in the whole Global Value Chain (GVC) including supplies from other industrial sectors, maintenance/repair and sales activities. A sectoral break down is shown in Table 1.

Table 1: Break down of employment, in millions, in EU automotive GVCs

\begin{tabular}{|l|l|}
\hline DIRECT MANUFACTURING & 2,685 \\
\hline Motor vehicles & 1,174 \\
\hline Bodies (coachwork), trailers and semi-trailers & 173 \\
\hline Parts and accessories & 1,339 \\
\hline INDIRECT MANUFACTURING & 968 \\
\hline Rubber tires and tubes, retreading and rebuilding of rubber tires & 140 \\
\hline Computers and peripheral equipment & 77 \\
\hline Electric motors, generators and transformers & 247 \\
\hline Bearings, gears, gearing and driving elements & 224 \\
\hline Cooling and ventilation equipment & 279 \\
\hline AUTOMOBILE USE & 4,657 \\
\hline Sale of motor vehicles & 1,652 \\
\hline Maintenance and repair of motor vehicles & 1,631 \\
\hline Sale of motor vehicle parts and accessories & 704 \\
\hline Retail sale of automotive fuel in specialized stores & 445 \\
\hline Renting and leasing of motor vehicles & 226 \\
\hline
\end{tabular}

The nature of automotive GVCs are rapidly changing, and while Western European countries such as Germany, France, and Spain have created strong plans to structure the development of this sector, the EU lacks such a development strategy and hence almost completely delegates its transformation to the market. The redefinition of production structures, with the creation of new and strong imbalances between countries, has been guided by the choices that companies, in particular multinationals, have taken without any kind of political intervention, aiming to reallocate production to increase profitability via the continuous search for the lowest labor costs.

While there has been a significant shift in production of vehicles from Western Europe to Eastern and Central Europe, ownership of the main carmakers remains for the most part in Western Europe and in Asia. In Eastern European countries, therefore, strategies concerning production location, investment, volume and model allocation are entirely in the hands of foreign manufacturers, attracted by low labor costs, low unionization rates and local government policies aimed at attracting FDIs. This particular distribution of production plants in Europe is intertwined with the public policies that European governments are defining in the automotive sector. 
Technological innovations and the increasing shift towards electrical vehicles play a significant role in this transformation and can have major impacts on employment going forward. In keeping with the Paris agreement there is a strong push towards the transformation of the entire transport sector towards zero emission levels. In fact, sales of petrol and diesel cars are falling very sharply, with a corresponding increase in "Electric" car sales. There is, however a range of electric from pure Battery Electric Vehicles (BEV) to hybrids, which combine Internal Combustion Engines (ICE) with battery propulsion. The choice of which vehicles are incentivized through subsidies is important, for example, as the number of components a BEV vehicle needs is much lower than that of a vehicle with an internal combustion engine, so a drastic shift to "pure" electric would have very significant employment consequences.

In this paper we explore the many challenges posed by transformations in the automotive industry. International division of labor within GVCs implies flows of intermediate goods that cross many national borders and therefore generate employment in as many countries. This means that any geographical recomposition of the structure of these chains generates a redistribution of employment between the areas involved. The role of EU wide regulations can play a critical role in this process, but there is a need to go beyond industrial policies focused merely on at creating the best environment for companies and develop a more comprehensive approach.

\section{The production of passenger cars in Europe}

First of all, let us focus on what has happened from the point of view of vehicle production, with particular attention to passenger cars ${ }^{1}$.

Table 2: Passenger cars production, by Country

\begin{tabular}{|l|l|l|l|l|}
\hline Country & $\begin{array}{l}\text { No. of cars } \\
\text { produced 1999 }\end{array}$ & $\begin{array}{l}\text { No. of cars } \\
\text { produced 2019 }\end{array}$ & $\begin{array}{l}\text { Difference in } \\
\text { absolute values }\end{array}$ & $\begin{array}{l}\text { Percentage } \\
\text { variation }\end{array}$ \\
\hline Germany & 5309524 & 4661328 & -648196 & -12.2 \\
\hline Spain & 2281617 & 2248019 & -33598 & -1.47 \\
\hline France & 2784469 & 1675198 & -1675198 & -39.8 \\
\hline Czech Republic & 348842 & 1427563 & 1078721 & 309.2 \\
\hline United Kingdom & 1786624 & 1303135 & -483489 & -27 \\
\hline Slovakia & 126503 & 1100000 & 973497 & 769.5 \\
\hline Italy & 1410459 & 542007 & -868542 & -61.5 \\
\hline Hungary & 125889 & 498158 & 372269 & 295.7 \\
\hline Romania & 88313 & 490412 & 402099 & 455.3 \\
\hline Poland & 546843 & 434700 & -112143 & -20.5 \\
\hline Turkey & 221041 & 982642 & 760601 & 342.5 \\
\hline
\end{tabular}

As shown by Table 2, in the period 1999-2019 all the main Western European countries have reduced

\footnotetext{
${ }^{1}$ Data from ANFIA
} 
their production volumes, while almost all Central and Eastern European countries, with the exception of Poland, have increased them.

Among Western countries, France is the one which displayed the greatest reduction in absolute terms (more than one million vehicles), followed by Italy (868 thousand). In Germany, production fell by approximately 648 thousand vehicles. On the contrary, Spain has experienced the lowest volume reduction (-33 thousand vehicles). In relative terms, volumes decreased by $39.8 \%$ in France, by $12.2 \%$ in Germany, and by $1.47 \%$ in Spain. Italy performed worst, with a $61.5 \%$ reduction.

As to Eastern Europe, Poland is the only country displaying a volume reduction (by more than 20\%); all the other Central and Eastern countries have experienced growth in this sector, with production increasing by 3-4 times - in the case of Slovakia even 7 times. The cases of the Czech Republic and Slovakia are particularly interesting. Both countries produced more than one million vehicles in $2019-$ $+309 \%$ and $+769 \%$, respectively, with respect to the previous year. Turkey also saw a very significant increase: $+342 \%$ with respect to the beginning of the year.

Let us now have a look at the main carmakers in Europe, and at the distribution of their plants in the various countries. Germany and France have at least one national carmaker: Volkswagen, BMW and Mercedes in the former case, Renault and PSA in the latter. Although domestic production is also carried out by foreign carmakers (e.g. Toyota and Mercedes in France, and PSA, Ford and Tesla in Germany), in both countries national carmakers represent the lion's share. Moreover, in both countries there are forms of state participation in some of the main carmakers: the French state is a shareholder, through BPI, of PSA with $12.23 \%$ and Renault with about 15\%. In Germany, the Lander of Lower Saxony is a shareholder of Volkswagen with about $12 \%$. Moreover, as we will see below the relation between governments and national carmakers is not limited to direct shareholdings.

Spain, on the other hand, does not have national carmakers; domestic production is controlled by foreign groups: Nissan, Renault, Volkswagen, PSA and Ford. Italy is a special case: the only national manufacturer is FCA. Besides having determined, through its strategic decision, the collapse in domestic production, FCA is now a multinational actor and its presence in Italy more and more marginal. Volkswagen, through its subsidiary Lamborghini, is also marginal with very low volumes.

In Central-Eastern Europe production growth is entirely attributable to foreign manufacturers, both European and Asian. It is interesting to note that German and French carmakers are very present in these countries, with several plants. Three German carmakers (Volkswagen, BMW and Mercedes) have plants in Hungary; Renault has a plant in Romania; PSA, Volkswagen and FCA are active in Poland; finally, Czech Republic and Slovakia host Volkswagen and PSA plants.

Asian manufacturers - and to a lesser extent Ford and Jaguar Land Rover - have plants in Central and Eastern Europe as well: Suzuki in Hungary, Hyundai in Czech Republic, Kia in Slovakia, Toyota (in partnership with PSA) in Poland.

In these countries, therefore, the strategies concerning production location, investment, volume and model allocation are entirely in the hands of foreign manufacturers, attracted by low labor costs, low unionization rates and local government policies aimed at attracting FDIs. This particular distribution of production plants in Europe is intertwined with the public policies that European governments are defining in the automotive sector.

\section{European Government Plans: Germany, France and Spain}


The Plans defined by German, French and Spanish Governments focus both on the demand side individual incentives for the purchase of new cars (especially with new, less polluting propulsion systems) - and on the supply side - support to investments, especially to strengthen their national supply chain of parts and components.

\subsection{The German Government Plan ${ }^{2}$}

To strengthen its production structure, Germany has launched the "Future Package", worth over 50 billion euros, to finance a series of measures over the next few years, many of which relate to the mobility sector. In general, as a horizontal measure, the state will support a tax allowance for research, providing support of up to 4 million euros per company, mainly funding research projects in the field of energy transition, digitization and the so-called Sector Coupling.

The German Plan is not limited to the automotive sector but more generally addresses the issue of mobility, also in terms of greater ecological and climate sustainability. The structural change in the automotive industry, which the German government intends to support, is part of this framework, with a view to build future-oriented value chains.

From the point of view of purchase incentives for clean vehicles and fleet replacement, the taxation system will aim to lower $\mathrm{CO} 2$ emissions. Through an environmental bonus, the German government seeks to promote the transformation of the vehicle fleet towards electric technologies. At the federal level the purchase bonus is doubled - for an electric vehicle worth 40,000 euros, the federal government's incentive increases from 3,000 to 6,000 euros. The taxation of purely electric company cars, set at $0.25 \%$, will involve a larger fleet, as the purchase price limit is increased from 40,000 to 60,000 euros.

A fleet replacement program will be launched for social services bodies for 2020 and 2021, with the aim of promoting electromobility in city traffic and supporting non-profit organizations in strengthening their fleets. A temporary fleet replacement program for craftsmen and SMEs for electric commercial vehicles is also planned.

The German government's choice is clearly intertwined with the investment plans of a number of German carmakers, aimed at electrifying their range of vehicles. Being a horizontal measure though, the incentive system could support national vehicle production, especially in view of the high volumes produced in Germany.

The German Plan also includes a bonus program for 2020 and 2021 for future investment by manufacturers in the whole supply chain, to promote new technologies, processes and systems.

Further public funds will be invested in the expansion of the charging infrastructure, the promotion of research and development in the field of electromobility and the production of batteries. The latter, as we will see below, is a key element in supporting new forms of propulsion, as the battery is crucial for electrified cars (both BEV and PHEV).

As anticipated, the German government's plan addresses the issue of mobility as a whole, with planned interventions in railways and maritime transport, and provides for a specific national hydrogen strategy to make Germany the world's leading supplier of cutting-edge hydrogen technologies, including the

\footnotetext{
${ }^{2}$ Zukunftspaket der Bundesregierung, June 2020
} 
construction of industrial production plants.

Table 3: German Government Plan: measures and funds

\begin{tabular}{|l|l|}
\hline Measure & Financial Commitment \\
\hline Environmental bonus for the transformation of the vehicle fleet & 2200 million \\
\hline Replacement of the fleets of social services agencies & 200 million \\
\hline Investment bonuses (technologies, processes, plants) & 2000 million \\
\hline Expansion of charging infrastructure & 2000 million \\
\hline Modernization of bus and truck fleet & 1200 million \\
\hline National hydrogen strategy $(*)$ & 9000 million \\
\hline Total & $\mathbf{5 6 0 0}$ million \\
\hline$(*)$ not counted in the total as only partially related to the transport sector & \\
\hline
\end{tabular}

\subsection{Spanish Government Plan ${ }^{3}$}

The Spanish government will present an ambitious Investment and Reform Plan to access Recovery Fund - Next Generation EU. Part of the resources will be allocated to strengthen the strategic autonomy, modernization, decarbonization and digitization of the Spanish automotive sector.

The objectives to be pursued include:

- boosting industrial investment, based on innovation projects which will turn Spain into a global platform for the production of carbon-neutral vehicles and components, such as batteries or renewable hydrogen;

- strengthening Spain's industrial autonomy, bringing production closer to consumers, in order to avoid the shortage of basic necessities at critical times such as the current one. In the automotive sector, this involves the production of cells, battery packs and other critical elements;

- integrating Spanish companies into the major strategic mobility chains and the automotive industry, turning the country into a European and global hub.

The Spanish Plan is divided into five pillars, which in turn consist of 21 measures in the fields of fiscal and regulatory reforms, logistics, competitiveness, training and professional qualifications, sustainable public procurement and strategic planning.

The aim of the first pillar is setting incentives for the renewal of the vehicle fleet, based on technological neutrality. It includes a set of measures to support the renewal of public (State and Local Authorities) car fleets. The second pillar focuses on supporting competitiveness and sustainability: it provides favorable credit policies for the Reindustrialization Plan (Reindus) by lowering interest rates on loans and widening the set of eligible projects. The Reindus loan program is expected to mainly benefit the automotive sector. The third pillar concerns R\&D\&I (research, development and innovation). It aims to support the use of hydrogen in the public and private mobility sector; industrial innovation and sustainable mobility projects (Moves Singulares); the improvement of 5G connectivity, both on primary and secondary road corridors and in automotive companies ("wireless factory") to accelerate changes in production chains. The fourth pillar provides for the use of tax leverage to

\footnotetext{
${ }^{3}$ Gobierno de Espagna, Plan del impulso de la cadena de valor de la industria de la automocion, June 2020
} 
support the competitiveness of the sector; the related financing has not been defined. Under this pillar, the government intends to encourage investment in process innovation in the Spanish automotive value chain through tax deductions. These measures should attract to Spain a greater share of the global production of electrified models and their components, as well as production activities related to the life cycle of batteries, charging infrastructure, connected mobility systems and other industrial ecosystems in the field of sustainable mobility. Finally, the fifth pillar refers to vocational training and retraining.

The last chapter of the plan is devoted to the objective of decarbonization of fleets and the production of new electric and electrified models. To this end, priority will be given to investments, in order to achieve an annual production of 700 to 800 thousand electrified vehicles (pure electric and plug-in) and the associated components - by 2030. From the point of view of production, the industry aims to achieve an increasing efficiency through the use 4.0 technologies - robotics, artificial intelligence, software, sensorialization, data management, etc.

Table 4: Spanish Government Plan: measures and funds

\begin{tabular}{|l|l|}
\hline Measure & Financial commitment \\
\hline $\begin{array}{l}\text { Renewal of the vehicle fleet (+ recharging infrastructure and new } \\
\text { forms of mobility) }\end{array}$ & 550 million \\
\hline Investments for competitiveness and sustainability & 2690 million \\
\hline R\&D\&I & 415 million \\
\hline Training & 95 million \\
\hline Total & $\mathbf{3 7 5 0}$ million \\
\hline
\end{tabular}

\subsection{French Government Plan ${ }^{4}$}

The French government has defined a very strong industrial plan to relaunch national automotive industry. The plan for a green and competitive industry is part of a broader strategy which, following the Covid-19 crisis, is being further strengthened and accelerated. In fact, the French Government had already defined a series of actions related to the automotive sector: an agreement signed in 2018 with the main actors in the supply chain, which defines reciprocal commitments around specific strategic axes; an Employment and Skills Commitment and Development Agreement (EDEC) to help companies in the supply chain adapt to changes; the Plan "Producing in France the cars of tomorrow", defining a Franco-German project for car batteries; and a support plan focused on subcontractors in the supply chain, with a wide range of loans, financing and other instruments. Along these lines, the French Government's Plan has three main goals: 1) renewing the car fleet in favor of clean vehicles; 2) investing to produce the vehicles of the future in France; 3) supporting companies in difficulty and protecting workers.

For the renewal of the car fleet, purchase incentives and conversion bonuses are provided for. The government issued specific directives for the renewal of public authorities' car fleets and the creation of recharging infrastructure for alternative (electric) propulsion. The bonus for electric vehicles (maximum price: 45,000 euros) is increased to 7,000 euros for individuals and 5,000 euros for companies. A 2,000 euros bonus is introduced for the purchase of plug-in hybrid vehicles (PHEV) with

\footnotetext{
${ }^{4}$ Gouvernment France, Plan de soutien à l'automobile - pour un industrie vert et compétitive, May 2020
} 
a price not exceeding 50,000 euros. This section also includes the objective of "Accelerating the development of charging stations for electric vehicles", to set up charging points in cities and territories, charging stations on major national axes and in residential buildings.

On the industrial side, the French Government's Plan aims to strengthen French companies and their supply chain. The first measure is precisely devoted to financial support for companies in the supply chain, setting up an investment fund to support projects for growth, innovation, diversification and consolidation. The shareholders will be the French State, BPI France (a Public Investment Bank), Renault and PSA. The second pillar is the Automobile Investment Fund, with which the state aims to diversify, modernize and transform the automobile sector in an ecological direction, providing guidelines for 4.0 transformation of processes and granting direct subsidies to investments. Moreover, the Fund will support projects for the development and industrialization of strategic components for the vehicle of the future "made in France". For example, the development and production of electric motors for hybrid petrol-powered vehicles belonging to the "small" segments (urban, peri-urban); the design, production and use of hydrogen systems or components or power electronics (electronic boards, inverters, etc.), now mainly produced in Asia. These projects will make it possible to locate a complete decarbonized vehicle production line in France.

The Plan also provides explicit support for the pilot plant for the production of batteries for electric vehicles, supported by France and Germany and led by SAFT (a subsidiary of the Total Group that produces batteries for various industrial sectors) and PSA. The objective of this joint venture is to develop and produce lithium-ion cells for electric car batteries.

On the workers' side, the French Government's Plan aims to implement a "massive skills development plan" to finance training in the so-called "priority actions" (health, digital robotics, etc.) in a broader sense than that mentioned above.

As a conclusion, the Plan calls for a series of collective commitments, in concert with manufacturers and the entire supply chain. The first aims to strengthen ecological conversion by increasing the range and number of clean vehicles. This also works to achieve compliance with European environmental regulations. To this end, one million electric and hybrid vehicles (in both versions) are expected to be produced by 2025. The second provides for the signing of a document by companies in the sector to strengthen the relationship between customers and suppliers, in order to tackle the transformation of the automotive industry. One of the most important measures is to reduce the location of plants outside France or Europe and - for carmakers - to give priority to French suppliers. Finally, a commitment is made to locate strategic activities in France - which will also have repercussions on the PSA-FCA merger.

Table 5: French Government Plan: measures and funds

\begin{tabular}{|l|l|}
\hline Measure & Financial commitment \\
\hline Electric vehicle purchase bonus (BEV and PHEV) & 535 million \\
\hline
\end{tabular}




\begin{tabular}{|l|l|} 
Conversion premium (scrapping) & 800 million \\
\hline Realization of charging points & 100 million (additional) \\
\hline $\begin{array}{l}\text { Support to companies in the supply chain (investment fund for the } \\
\text { supply sector for growth, innovation, diversification and } \\
\text { consolidation projects) }\end{array}$ & 600 million \\
\hline $\begin{array}{l}\text { Investment fund (for processes modernization) } \\
\begin{array}{l}\text { Support for development and innovation (projects for the } \\
\text { development and industrialization of strategic components of the } \\
\text { value chain of the vehicle of the future "made in France") }\end{array}\end{array}$ & 200 million \\
\hline Production of batteries for electric vehicles & 850 million \\
\hline Training of workers & 500 million \\
\hline Total & $\mathbf{3 7 3 5}$ million \\
\hline
\end{tabular}

\section{The European Strategy}

The EU lacks a development strategy for the sector and hence almost completely delegates its transformation to the market. On the other hand, the redefinition of production structures described above, with the creation of new and strong imbalances between countries, has not happened by chance: it has been guided by the choices that companies, in particular multinationals, have taken without any kind of political intervention, aiming to reallocate production to increase profitability via the continuous search for the lowest labor costs.

This reallocation of production volumes, both through relocation processes and FDIs, was possible thanks to the freedom of movement of capital, companies and goods. Europe's main policies and strategies in the automotive sector can be listed as follows:

- Training and Skills;

- Access to Finance for SMEs;

- Technical Harmonization;

- Regulatory Policies;

- Conclusions and Recommendations by High Level Group GEAR 2030;

- European Battery Alliance

The Blueprint for Sectoral Cooperation on Skills ${ }^{5}$ promotes upskilling and the acquisition of digital, mechatronic, mechemtronic and transversal skills related to new technologies. Moreover, it develops programs for inter-generational learning and educational tools, vocational training and apprenticeship programs. Finally, it aims to develop hybrid programs in vocational education and training and universities, including seminars on industry subjects and apprenticeships to put skills into practice, and it wishes to establish long-term cooperation and exchange of good practice among industry stakeholders, research institutes and education and training providers.

The COSME (Competitiveness of Enterprises and Small and Medium-sized Enterprises) project, in its turn, is focused on addressing upskilling and reskilling strategies for SMEs in the automotive sector. Basically, this policy, the only one in the field of employment, is based on the deep-rooted conviction

5 European Commission (2017a). 
of European institutions that active labor policies should be limited to training and skills, without any direct intervention in the creation and/or protection of jobs.

The program provides SMEs with two financial instruments to access the resources: the Loan Guarantee Facility (LGF: COSME budget will fund guarantees and counter-guarantees for financial intermediaries to loan and lease finance to SMEs) and The Equity Facility for Growth (EFG: COSME budget dedicated to investments in risk-capital funds that provide venture capital and mezzanine finance to expansion and growth-stage SMEs, in particular those operating across borders).

Technical harmonization of motor vehicles has been designed to allow car manufacturers to access as large a market as possible. Harmonization in the EU is based on the Whole Vehicle Type-Approval System (EU WVTA) and, as the EC states, "enables manufacturers to benefit from the EU Single Market". Manufacturers can obtain certification for a vehicle type in one EU country and then sell it EU-wide without the need for further tests.

Regulatory Policies, in addition to regulating safety aspects, have recently focused on polluting emissions to push towards new forms of propulsion. In particular, the Regulation ${ }^{6}$ on new vehicle $\mathrm{CO} 2$ emission limits opens with a very significant policy statement: "In order to contribute to the objectives of the Paris agreement, the transformation of the entire transport sector towards zero emission levels must be accelerated." For this reason, the objective that emissions from vehicles with conventional combustion engines must be further reduced in the period after 2020 is stressed. Zero and low-emission vehicles must gain a significant market share by 2030 .

In order to achieve this ecological transition, the Regulation calls for an integrated approach to public and private investment in research and innovation, an increased supply of low and zero emission vehicles, recharging and refueling infrastructures, sustainable supply of materials and sustainable production, reuse and recycling of batteries. The only industrial concern emerges when the Regulation recalls that, although the EU is one of the leading manufacturers of motor vehicles and can gain technological leadership in the global automotive sector, it faces increasing competition. In order to keep its global competitiveness, the Union needs a regulatory framework, including a special incentive in the field of zero and low-emission vehicles. Once again, therefore, European policies merely call for public intervention in terms of regulation and incentives without providing for other, more concrete and direct instruments of intervention.

The concerns of the Community legislator, in the context of the emissions reduction process, also involve competition issues, in order to avoid unjustified distortions; in addition, it is proposed to encourage the automotive industry to invest in new technologies by promoting eco-innovation and introducing a mechanism to take note of future technological evolution.

The conclusions and Recommendations by High Level Group GEAR $2030^{7}$ share the same logic: higher production costs compared to other markets - especially in Asia - are due to the stricter level of regulation applied in the EU. However, the Report maintains, in the next years Original Equipment Managers (OEMs) operating in Europe will benefit from higher profits as they will be able to capture the market share of foreign OEMs, the latter not being able to comply with the stricter European regulation. Further, according to the Report, European OEMs could gain market share in China because

\footnotetext{
${ }^{6}$ Regulation (EU) 2019/631 of the European Parliament and of the Council of 17 April 2019 setting CO2 emission performance standards for new passenger cars and for new light commercial vehicles.

7 European Commission (2017b).
} 
they will be able to anticipate the regulatory restrictions that will also be adopted in that country. As regulations in other markets begin to converge with European regulation, the cost advantage for those countries would decline.

These forecasts appear overly optimistic, given that Asian carmakers, particularly Japanese and Chinese ones, seem to be very well positioned in the new electrical technologies and therefore it seems risky to assume that market share could be gained in China.

Wage differentials are not considered a problem, since wages in China and India are increasing compared to the European level. In this case too, it seems very difficult to support this thesis, which, moreover, pretends that wage differentials do not exist within the EU itself. It therefore becomes possible to state that "Regulation is thus the key to leveling the playing field between EU and other markets over time", even if "production costs in the EU are anticipated to remain the highest until 2050."

In this respect, these recommendations are extremely worrying from a social point of view: "There are known structural issues in the EU automotive contributing to these high costs, for example excess manufacturing capacity, high labor costs, etc. To tackle this issue, the EC should support the EU automotive industry as it seeks to reduce its uncompetitive overheads, through ensuring that it is able to effectively streamline manufacturing and increase the use of automation, whilst also supporting it as it seeks to become a global leader in the development of manufacturing 4.0. To this end, the EU can provide financial support to encourage and facilitate collaboration and strategic alliances which help companies share the costs of R\&D investments as well as to develop new business models."

The conclusion is that the European Commission should finance initiatives, such as 4.0 transformations and Lean Production, aimed at intensifying workers' performance to increase profitability for companies. The Report also advocates demand-side measures (incentives), which must, however, be directed towards the purchase of clean vehicles, regardless of the carmakers producing them - and its geographical location. Moreover, again in support of the profitability of the EU automotive industry, the Report highlights the higher production costs for new types of vehicles (both in the case of electric mobility and connected and autonomous vehicles), so the first target to be reached should be cost reduction. In order to achieve this objective, support tools in the field of $\mathrm{R} \& \mathrm{D}$, Public Private Partnership to support the funding of large-scale testing and deployment of infrastructure are called up. No reference is made to production volumes and, therefore, to production capacity and employment levels.

The document keeps the same approach to the effects that the shift towards e-mobility might have on supply companies: "In particular, much of the traditional automotive industry is poorly-equipped to supply the relatively simple, but highly capital intensive components such as batteries, or battery management systems, with most of the major global players originating outside of Europe, e.g. in Japan, Korea and the US".

Again, the document calls for the usual recipes: "In order to ensure that the EU-made content on xEVs remains high, the EC should seek to support the development of native capability in these crucial technology areas. Initiatives such as its Flagship battery initiative and R\&D funding to support the development of these capabilities could go some way towards achieving this aim and securing an ongoing role for the traditional EU automotive industry in the future production of xEVs". 


\section{Electric vehicles: what are we talking about?}

Public opinion generically refers to electric vehicles without distinguishing the various types - which are very different from each other. An electric vehicle, generally understood, is a vehicle that uses electric propulsion; but this is not necessarily the only form of propulsion.

\section{Battery electric-vehicles}

Vehicles that use electric technology as the only form of propulsion, without an internal combustion engine, are Pure Electric Vehicles. When we refer to them we use the term Battery Electric Vehicles (BEV). There is substantial consensus in defining BEV. According to a study by the JRC (Joint Research Center) of the European Commission, "Battery Electric Vehicles refer to vehicles propelled solely by electric motors. The source of power stems from the chemical energy stored in battery packs which can be recharged on the electricity grid." According to Chan et al (2010) BEVs are propelled by an Energy Management System running on electricity stored in a battery: the propulsion is an electric motor drive, the energy storage system involves battery and supercapacitator, and finally, as energy source and infrastructure they use the electrical grid, with charging facilities.

More in detail, Ehsani et al. (2005) explain that the drive train consists of three subsystems: 1) electric motor propulsion, 2) energy source, and 3) auxiliary. The electric propulsion subsystem involves a vehicle controller, power electronic converter, electric motor, mechanical transmission, and driving wheels. The energy source subsystem involves the energy source, the energy management unit, and the energy refueling unit, and finally the auxiliary subsystem involves the power steering unit, the hotel climate control unit, and the auxiliary supply unit.

There are several possible configurations that the authors list in six possibilities:

(a) (...) an electric propulsion replaces the IC engine of a conventional vehicle drive train. It consists of an electric motor, a clutch, a gearbox, and a differential. The clutch and gearbox may be replaced by automatic transmission. The clutch is used to connect or disconnect the power of the electric motor from the driven wheels. The gearbox provides a set of gear ratios to modify the speed-power (torque) profile to match the load requirement (...). The differential is a mechanical device (usually a set of planetary gears), which enables the wheels of both sides to be driven at different speeds when the vehicle runs along a curved path.

(b) (...) an electric motor that has constant power in a long speed range (...), a fixed gearing can replace the multispeed gearbox and reduce the need for a clutch. (...)

(c) (...) electric motor, the fixed gearing, and the differential can be further integrated into a single assembly while both axles point at both driving wheels. (...)

(d) the mechanical differential (...) replaced by using two traction motors. Each of them drives one side wheel and operates at a different speed when the vehicle is running along a curved path.

(e) (...) the traction motor can be placed inside a wheel. (....) (...) A thin planetary gear set may be used to reduce the motor speed and enhance the motor torque. (...)

(f) (...) the out-rotor of a low-speed electric motor in the in-wheel drive can be directly connected to the driving wheel. The speed control of the electric motor is equivalent to the control of the wheel speed and hence the vehicle speed.(...)"

Ehsani et al. (2005), pp. 101-2

Regardless of technical details, according to the definition of Acea" "Battery electric vehicles (BEVs) are fully powered by an electric motor, using electricity stored in an on-board battery that is charged by plugging into the electricity grid", i.e. a vehicle that has no internal combustion engine.

\footnotetext{
8 Nemry et al (2009).

9 https://www.acea.be/industry-topics/tag/category/electric-vehicles
} 


\section{Hybrid vehicles}

Significantly different is the case with hybrid vehicles, which also include an internal combustion engine. In these kinds of vehicles, in fact, propulsion comes from two or more types of energy sources or converters, and at least one of them can deliver electrical energy.

There are different types of hybrid vehicle configurations; the main are: "Series-Hybrid", "ParallelHybrid", "Combination-Hybrid" and "Complex-Hybrid".

\section{Series-Hybrid}

The first one is the "Configuration of Series", where the series is composed of an Internal Combustion Engine (ICE), generator, power converter, motor, and battery. "There is no mechanical connection between ICE and transmission, thus ICE can operate at maximum efficient point by regulating the output power of battery to satisfy the required power of vehicle. (...) Since the motor is the final and sole drive device, the motor must be larger enough to satisfy performance of vehicle, and thus the regenerative braking power almost can be stored in battery by motor." (Shen et al 2011) In this case, as stressed by Nemry et al (2009), only the electric motor provides power to drive the wheels, and the sources of electrical energy are either the battery pack (or ultra capacitors) or a generator powered by a thermal engine.

Since a series hybrid drive train is a drive train where two power sources feed a single powerplant (electric motor) that propels the vehicle, we can see different solutions as highlighted by Eshani et al. (2005) p.122:

1. Pure electric mode: The engine is turned off and the vehicle is propelled only by the batteries.

2. Pure engine mode: The vehicle traction power only comes from the engine-generator, while the batteries neither supply nor draw any power from the drive train. The electric machines serve as an electric transmission from the engine to the driven wheels.

3. Hybrid mode: The traction power is drawn from both the engine-generator and the batteries.

4. Engine traction and battery charging mode: The engine-generator supplies power to charge the batteries and to propel the vehicle.

5. Regenerative braking mode: The engine-generator is turned off and the traction motor is operated as a generator. The power generated is used to charge the batteries.

6. Battery charging mode: The traction motor receives no power and the engine-generator charges the batteries.

7. Hybrid battery charging mode: Both the engine-generator and the traction motor operate as generators to charge the batteries.

\section{Parallel-Hybrid}

The second one is "Parallel-Hybrid" in which both the electric motor and thermal engine can provide power in parallel to the same transmission. Since both the electric motor and Internal Combustion Engine can deliver power in parallel to drive the vehicle, "ICE and motor can drive, respectively, or together".

While, as stressed by Prajapati et al. (2014) in "Series-Hybrid" the Internal Combustion Engine is decoupled from the driven wheels, in "Parallel-Hybrid" there is "direct mechanical connection between the hybrid power unit and the wheels. In addition, this layout has an electric traction motor that drives the wheels and can recuperate a share of the braking energy, in order to charge the batteries (regenerative braking) or help Internal Combustion Engine during acceleration conditions. In fact, Internal Combustion Engine and electric motor are coupled by a mechanical device".

There are several configurations depending on the structure of the mechanical combination between the Internal Combustion Engine and the electrical motor: torque-coupling, speed-coupling and a merge of both previous couplings. 
With regards to torque-coupling and speed coupling, as detailed by Eshani et al. (2005), "The torque coupling adds the torques of the engine and the electric motor together or splits the engine torque into two parts: propelling and battery charging (...)". The mechanical torque coupling has two inputs: "One is from the engine and one is from the electric motor. The mechanical torque coupling outputs to the mechanical transmission (...) There are a variety of configurations in torque coupling hybrid drive trains. They are classified into two-shaft and one-shaft designs. In each category, the transmission can be placed in different positions and designed with different gears, resulting in different tractive characteristics". The same authors states that in the speed-coupling, "The powers from two powerplants may be coupled together by coupling their speeds", in this case the speeds of the two powerplants are decoupled; therefore, the speed of both the powerplants can be chosen freely. Finally, "By combining torque and speed coupling together, one may constitute a hybrid drive train in which torque and speed coupling states can be alternatively chosen."

\section{Combination-Hybrid}

The Combination is obtained by combining "Series" and "Parallel" solutions. In fact, the "Combination-Hybrid", as states by Shen et al. (2011) "incorporates the features of both series and parallel HEV, an additional mechanical connection between ICE and transmission is added compared with the series hybrid, and also an additional generator between ICE and power converter is added compared with the parallel hybrid. Although the complexity of structure leads to more costly manufacturing technologies, it is more flexible in control." The flexibility is determined by the fact that, as stressed by Nemry et al (2009), combining the advantages of both parallel and series hybrid concepts, "this relatively complex architecture allows running the vehicle in an optimal way by using the electric motors only, or both the ICE and the electric motors together, depending on the driving conditions".

\section{Complex-Hybrid}

Finally, in the "Complex-Hybrid" two separate mechanical links enable it to obtain a light transmission system and a flexible mounting in which, for example, the front wheels are powered by hybrid propulsion, while the rear wheels have a pure electric system.

\section{How these definitions are utilized in the automotive industry}

Using the classification by Cardoso et al. (2019) and by Enang and Bannister (2017), the large family of electrified vehicles can be subdivided as follows:

- Micro-Hybrid, which as a low degree of hybridization: the electric motor, in the form of a small integrated starter/generator, is only used to shut down the engine when the vehicle comes to a complete stop and start it up when the driver releases the brake pedal. For traction while moving, the vehicle is propelled only by Internal Combustion Engine and, in this way, the Energy Management does not provide additional torque to the vehicle.

- Mild-Hybrid is similar to the Micro one but have an increased size of the Energy Management (integrated alternator/starter motor) and a battery for power assist during vehicle propulsion.

- In the Full-Hybrid model, the Energy Management and batteries are larger than those of the two previous models; this enable that the electric motor can be used as the sole power source. Compared to the previous two, the engines are always smaller and the Energy Management Systems is more sophisticated.

- Finally, the Plug-in Hybrid Electric Vehicle (PHEV) has the same configuration of Full-Hybrid, 
but with the addition of an external electric grid charging plug. It is also characterized by much bigger electrical components (electric motor and battery) and a smaller engine. Using higher capacity electrical components, PHEVs can run on electric power for long periods of time and distance. Thanks to these features, Plug-in Hybrid Electric Vehicle can use, independently or not, fuel and electricity, both of them rechargeable from external sources (petrol pumps and electric charging plugs). According to JCR (2009), "It can indeed be considered as either a BEV supplemented with an internal combustion engine (ICE) to increase the driving range, or as a conventional HEV where the all-electric range is extended as a result of larger battery packs that can be recharged from the grid".

Both the classification of technologies and the classification used in the automotive sector are useful to understand that in the large family of electrified vehicles there are many different models; most of which continue to maintain the internal combustion engine. Only the Battery Electric Vehicle (BEV) is propelled solely by electric motors, with a battery packs sourcing the power (battery packs are recharged on the electricity grid).

This clarification is important both to correctly read the data on the market shares of the various propulsion technologies and to frame the issue of components with the corollary of employment levels.

\section{Sales figures for electric cars in Europe}

In 2019, a total of $15,700,988^{10}$ passenger cars were registered in EU-28 (which still included the UK) and EFTA area (Iceland, Liechtenstein, Norway, Switzerland). There are 365,377 BEV vehicles registered, but Norway has more than 60,000 , so taking only the EU into account, BEVs number 290,928; of these, over 67,000 were registered in the Netherlands. In the case of the enlarged EFTA market, the market share of $\mathrm{BEV}$ is $2.3 \%$, while taking the EU alone into account it is $1.9 \%$.

There are 198,889 registered PHEV vehicles, with consistent numbers in Norway; taking only the EU into account there would be 174,139. In the case of the enlarged EFTA market, the market share of PHEVs is $1.3 \%$, whereas if only the EU is taken into account, it is $1.1 \%$. The situation is better for hybrid vehicles with Full-Hybrid and Mild-Hybrid technologies: in the case of the enlarged market there are 931,934 registered vehicles, while taking only EU into account there are 891,342, with market shares of $5.9 \%$ in both cases.

Gasoline cars, in the enlarged market, are 9,184,935, while diesel cars are 4,756,440, with market shares of $5.9 \%$ in both cases: $58.5 \%$ and $30.3 \%$.

Table 5 shows registration figures for some European countries: the 5 largest markets (France, Germany, Italy, Spain and the UK), the two countries where BEV vehicles are most widespread (the Netherlands and Norway) and some countries in Central and Eastern Europe (Czech Republic, Hungary and Poland).

Table 6: Cars registrations, main European countries

\begin{tabular}{|l|l|l|l|l|l|}
\hline Country & Petrol & Diesel & $\begin{array}{l}\text { Mild e Full } \\
\text { Hybrid }\end{array}$ & BEV & PHEV \\
\hline France & $1,281,795$ & 755582 & 106.84 & 42764 & 18592 \\
\hline
\end{tabular}

10 The data are taken from the databases of ANFIA. Data for Cyprus, Croatia, Malta, Luxembourg are not available. 


\begin{tabular}{|l|l|l|l|l|l|} 
Germany & $2,136,891$ & $1,152,733$ & 193902 & 63491 & 45348 \\
\hline Italy & 852797 & 763097 & 109922 & 10668 & 6507 \\
\hline Spain & 765131 & 350778 & 108684 & 10044 & 7432 \\
\hline UK & 1498640 & 583488 & 156178 & 37850 & 34984 \\
\hline Netherlands & 316676 & 32836 & 23201 & 67695 & 4901 \\
\hline Norway & 22355 & 22823 & 17547 & 60345 & 19295 \\
\hline $\begin{array}{l}\text { Czech } \\
\text { Republic }\end{array}$ & 173885 & 69253 & 7873 & 756 & 473 \\
\hline Hungary & 114656 & 31063 & 9170 & 1833 & 1106 \\
\hline Poland & 555150 & 394519 & 38716 & 1490 & 1200 \\
\hline EU & 8964181 & 4650773 & 891342 & 290928 & 174139 \\
\hline EU+EFTA & 9182935 & 4756440 & 931934 & 365377 & 198889 \\
\hline
\end{tabular}

Table 6 shows the market shares (\%) of BEV vehicles in the above-mentioned markets, with the trend over time.

Table 7: Market shares (\%), BEV vehicles

\begin{tabular}{|l|l|l|l|l|}
\hline Country & $\mathbf{2 0 1 6}$ & $\mathbf{2 0 1 7}$ & $\mathbf{2 0 1 8}$ & $\mathbf{2 0 1 9}$ \\
\hline France & 1.1 & 1.2 & 1.4 & 1.9 \\
\hline Germany & 0.3 & 0.7 & 1.1 & 1.8 \\
\hline Italy & 0.1 & 0.1 & 0.3 & 0.6 \\
\hline Spain & 0.2 & 0.3 & 0.5 & 0.8 \\
\hline UK & 0.4 & 0.5 & 0.7 & 1.6 \\
\hline Netherlands & 1.1 & 2.4 & 6 & 15.2 \\
\hline Norway & 15.7 & 20.9 & 31.2 & 42.4 \\
\hline Czech Republic & & 0.1 & 0.3 & 0.3 \\
\hline Hungary & & 0.6 & 1 & 1.2 \\
\hline Poland & & 0.1 & 0.1 & 0.3 \\
\hline
\end{tabular}

Table 7 shows sales figures for the first half of 2020, in the EU/UK/EFTA Area, with relative increases in percentage terms compared to the first half of the previous year. 
Table 8: Sales, first half of 2020

\begin{tabular}{|l|l|l|}
\hline Type of vehicle & Sales & Growth rate (\%) \\
\hline BEV & 221171 & 34.8 \\
\hline PHEV & 178250 & 114.3 \\
\hline HEV & 514519 & 15.7 \\
\hline Petrol & 2677035 & -45.4 \\
\hline Diesel & 1415437 & -46 \\
\hline
\end{tabular}

As we can see, therefore, sales of petrol and diesel cars are falling very sharply, giving a very strong signal of impending collapse of the automotive market (not only in Europe, but also worldwide). "Electric" cars are growing: the one with the highest percentage increase is PHEV vehicles, while BEV vehicles are growing by $34.8 \%$.

One figure deserves to be stressed: the sales of BEV vehicles are growing in almost all countries, with the exception of the Netherlands (-16\%) and Norway (-19\%), which had previously reached the highest numbers, both in terms of volumes sold and market shares. In Norway, ${ }^{11}$ sales of electric cars have been supported with very generous incentives: for example, BEVs vehicles have been exempted from registration tax and from VAT on purchase, for BEVs (and PHEVs) Circulation tax rebates was reduced, in several municipalities BEVs pay much less for the parking fee, electric cars are exempt from paying for the use of regional toll roads (but from 2019, electric cars will have to pay the tolls, but at a lower fee), etc. The reconsideration of these incentives by Norwegian authorities might have influenced this first and partial results for 2020 .

These considerations can be extended to other markets as well, as we read in the IEA document ${ }^{12}$ about the fact that purchase subsidies were reduced in key markets: "China cut electric car purchase subsidies by about half in 2019 (as part of a gradual phase out of direct incentives set out in 2016). The US federal tax credit program ran out for key electric vehicle automakers such as General Motors and Tesla (the tax credit is applicable up to a 200,000 sales cap per automaker). These actions contributed to a significant drop in electric car sales in China in the second half of 2019, and a 10\% drop in the United States over the year. With $90 \%$ of global electric car sales concentrated in China, Europe and the United States, this affected global sales and overshadowed the notable 50\% sales increase in Europe in 2019, thus slowing the growth trend."

In fact, the very high acquisition costs of electric cars are one of the elements contributing to a still very limited diffusion of these technologies. So it should come as no surprise that, in a mirror image, in countries where incentives are being questioned, sales of BEVs are declining, while in countries that introduce incentives, sales are increasing. The fact remains, however, that both sales volumes and market shares of BEV vehicles are still very low.

This is also important to discuss employment levels. The number of components a BEV vehicle needs is much lower than that of a vehicle with an internal combustion engine, so a drastic shift to "pure" electric would have very significant employment consequences. In BEV vehicles the propulsion system linked to the internal combustion engine, which consists of many parts (cylinder head; valves;

11 OECD/IEA, Nordic EV Outlook 2018.

12 IEA, Global EV Outlook 2020. 
camshaft; crankshaft; pistons; oil pump; turbochargers; fuel tank/pipeline/injectors, starter motor, etc.), including the exhaust system, disappears completely. See Gaddi \& Garbellini (2019) for details.

Hybrid vehicles, on the other hand, are the ones that need the higher number of components, as they combine both internal combustion engine and electric motor technology. In this case, therefore, the environmental objectives of reducing emissions are positively intertwined with social concerns about the employment levels of the sector.

\section{Batteries}

EU policies also show strong limitations and contradictions on the issue of batteries for electric vehicles. This issue is particularly relevant for two reasons: a) the battery is the key element of electric vehicles, b) while many carmakers produce internal combustion engines within their Group (or in any case do so through subsidiaries/partnerships), in the case of batteries they are mainly turning to external suppliers, ${ }^{13}$ most of which are located in Asia.

But what do we mean by "batteries for electric vehicles"? Batteries are used for Mild-Hybrid, FullHybrid, PHEV and BEV; they are basically the NiMH battery (nickel metal hydride battery) and Li-on battery (lithium-ion battery). The battery consists - in sequence - of cells, modules and pack:

- a cell consists of anode and cathode, electrolytic separator, current collectors and casing: these components are assembled into and individual cell;

- a module - which includes the cell - consists of casing, cooling system and connectors, and finally; a battery pack is composed, in addition to the modules, also by battery management system, sensors, cabling, cooling system and casing.

We can therefore highlight the following as macro-phases of the Battery Cells supply chain: raw materials, processed materials, components, cells, assembly pack. The supply chain for the production of Lithium batteries for vehicles is made up of several phases: the first is obviously the extraction of raw materials, followed by their refining, which involves a dedicated industrial activity. The chemically active materials thus obtained are used for the production of components and cells (assembly cells) that make up the parts of the modules (assembly modules) that in turn make up the complete battery (assembly pack).

In each of these phases, Europe proves to be very weak. Raw materials include Cobalt, Lithium, Natural Graphite, Nickel, Manganese, Silicon, Copper, Titanium, Iron, Aluminum, Fluorspar, Phosphate, Tin. In this phase, according to a study by European Commission-JCR ${ }^{14}$ quoting a work by Blagoeva et al (2019) Europe weighs only, 2\%, Chile 6\%, Australia 7\%, China 30\% and Others 55\%. By way of example, we cite, among other critical materials:

- cobalt, supplied mainly by Congo $(54 \%-64 \%)^{15}$, by China (8\%), Canada (6\%), New Caledonia (5\%) and Australia (4\%); the main companies are Glencore (Multinational), China Molybdenum (Chinese), Jinchuan (Chinese), Norislk Nickel (Russian) ${ }^{16}$

- lithium, supplied to the extent of about $90 \%$, by Chile, Australia and Argentina; the main companies are Albermarle (USA), SQM (Chilean), Tianqui (Chinese), FMC (USA), Galaxy Resources (Australian), Jiangxi Gonfeng (Chinese)

13 Connell Garcia et al (2020).

14 Data from: European Commission, JRC Scientific Information Systems and Databases - RMIS - Raw Materials in the Battery Value Chain, 2020.

15 European Commission (2018).

16 For the names of the companies involved in the different stages of the chain we refer to: Sharova et al (2020). 
- natural graphite, supplied by China (around 70\%), followed by Brazil; the main companies are China Carbon Graphite Group (Chinese), Arunachal Pradesh (Indian), Extrativa Metalquim-ica (Brazilian), SRG Graphite (Canadian).

Obviously this first phase strictly depends on whether or not these materials are available in the different geographical areas; by contrast, the following phases imply the presence of an industrial structure capable of carrying out the different manufacturing processes.

The first industrial phase is the refining of raw materials; the main producers are:

- for refined cobalt: China (46\%), Finland (13\%), Canada and Belgium (both $6 \%$ ); major companies are: Huayou (located in China), Freeport Cobalt (located in Finland), Sinchuan (located in China);

- for refined lithium: China has the majority of hard-rock minerals refining facilities, while Chile $(32 \%)$ and Argentina (20\%) are the main country suppliers of refined lithium capacity from brine operations;

- for refined nickel: the main producer is China with about a 30\% share, followed by Russia, Japan, Canada and Australia; the major companies are: Vale (located in Brazil, Canada etc.); Norislk Nickel (located in Russia); Glencore (located in Canada);

- for refined manganese the key companies are: Hongxin (Chinese, located in Ukraine), Hunan Dongfang (Chinese, located in China and Ukraine); Ningxia (Chinese, located in China).

From the point of view of the Anode and Cathode materials production, Europe only accounts for $7 \%$, while Asia for 86\% (China 48\%, Japan 29\% and South Korea 9\%); and Others for 7\%.

Lithium-nickel-cobalt-manganese-oxide, also known as NMC, has been established as the best cathode material. The key players within the NMC production process are both cell manufacturers (which we will see later) and some companies: Hunan ShanShan (located in China), Xiamen Tungsten (located in China), Nichia (located in Japan) and L\&F (located in China).

Graphite is also used for the production of the anode. In this case the key companies are: BTR (located in China - the largest company in this sector with 49\% market share), Mitsubishi (located in Japan), Hitachi (located in Japan), Nippon Carbon (located in Japan) and Posco Chemtech (located in Korea); while in the case of synthetic graphite they are: Shanshan (China), Hitachi (Japan), JFE (Japan) Mitsubishi (Japan) and Showa Denko (Japan).

The next step involves the use of refined/processed materials to produce cell components, in particular the anode and cathode (electrode). In this case as well the role of Europe is very worrying: in the production of anode, cathode and electrolyte separators Europe only accounts for $8 \%$, while Asia again accounts for $86 \%$ (with the same percentage of the above mentioned phase: China $48 \%$, Japan $29 \%$ and South Korea 9\%); and Others for 6\%. The only European company in this sector is Umicore (Belgium); other main players are Pulead (China), Dow (USA) and four Japanese companies: Nichia, Mitsubishi Electric, Hitachi and Sumitomo. Among the companies that build and supply plants/equipment necessary for the production processes of this phase, however, there are many European companies, in particular German: Eirich, Burkle, Kroenert, Durr Megtec, Coatema.

The next step in the production chain is the cell assembly that follows the electrode manufacturing; in this case as well cell manufacturing capabilities are dominated by Asian companies (in part thanks to their know-how in consumer electronics and in the first automotive projects).

Here the role of Europe, for the time being, is dramatically marginal - accounting only for $0.2 \%$ of 
total production; China accounts for $66 \%$, South Korea for $13 \%$, USA for $13 \%$ and Others for $8 \%$. All the main players are Asian companies: LG Chem, SK Innovation and Samsung SDI from South Korea; Panasonic from Japan; BYD, CALB and CATL from China. These companies, generally, produce both cells, modules and packs. In this case as well we find several European companies among equipment suppliers (in particular German companies): Trumpf, Manz, Jonas \& Redmann, Harro Hoflinger, Digatron, in addition to other manufacturers from USA, Canada etc.

Within Europe, the future relocation of large battery cell production plants seems to be very unbalanced, with several countries being excluded. An initial mapping of the plants that will be present in Europe for the production of batteries, carried out by Transport \& Environment, ${ }^{17}$ has shown that the largest factories will be located in only a few countries: Germany, Hungary, Poland, Sweden, UK.

To the projects should be added the important French project by SAFT-PSA consortium (in cooperation with Germany) we mentioned in the paragraph on the French Government's automotive plan. Other smaller projects are planned in the UK and other countries.

A precise reconstruction of the number and location of battery production plants in Europe, based on the manufacturers' announcements, is a very difficult task as projects and intentions change continuously. We consider it useful, however, to recall this first mapping to signal that the absence of a European industrial policy in this sector could lead to further imbalances between EU Member States.

In October 2017 the European Battery Alliance has been launched as part of a "new industrial policy strategy", showing all the weaknesses of a market-based approach that limits industrial policies to horizontal ones. In 2018, the European Commission adopted the strategic action plan on batteries as part of the third mobility package "Europe on the move". The plan includes a series of measures to support initiatives aimed at creating a battery value chain in Europe.

This Plan aims to:

- ensure access to raw materials from resource-rich third countries, facilitate access to European sources of raw materials and access, through recycling, to secondary raw materials within a circular battery economy;

- support European industrial-scale battery cell production and create a complete value chain in Europe by bringing together key industrial players and national and regional authorities; working in partnership with Member States and the European Investment Bank to support production projects;

- strengthen industrial leadership through enhanced EU research and innovation support for advanced (e.g. lithium-ion) and breakthrough (e.g. solid state) technologies in the battery sector; this should aim to support all stages of the value chain (advanced materials, new chemicals, production processes, battery management systems, recycling, business model innovations), be closely integrated into the industrial ecosystem and help accelerate the diffusion and industrialization of innovations;

- develop and strengthen a skilled workforce in all parts of the battery value chain in order to fill skills gaps through training and retraining.

In April 2019, the European Commission published a report on the implementation of the abovementioned strategic plan, where it acknowledged that the European share of world cell production is only $3 \%$ compared to the $85 \%$ of Asia, which could lead to a heavy dependence of European industry

17 Transport \& Environment, Electric Surge: carmaker's electrification across Europe 2019-2025, 2019. 
on battery cell imports. This dependence would become even heavier if the sales forecasts for electric vehicles were to be realized, which would bring the demand for lithium-ion batteries to $660 \mathrm{GWh}$ in 2023, 1,100 GWH in 2028 and 4,000 GWh by 2040, compared to only 78 GWh today.

Obviously, these estimates have been made assuming that the expected replacement rates of ICE cars with electricity will be achieved.

In order to reduce the level of dependency, the European Commission has launched a series of initiatives involving:

- research \& innovation to bring the next generation of battery technologies to market through specific financing instruments in the EU budget; in this context, the European Investment Bank has provided 52 million euro loan for a demonstration line in Sweden, and other projects in Croatia, France, Greece and Sweden have benefited from the European Strategic Investment Fund;

- the industrial dissemination of innovative solutions: in this area, the European Battery Alliance has set up a network led by EIT InnoEnergy which has announced investments for 100 billion euro for the production of raw materials and batteries by several European consortia (plants are planned in Poland and Finlndia to produce essential materials for batteries).

Once again, we can see how the industrial policies decided by the EU institutions are purely horizontal: i.e. aimed at creating the best environment for companies, but without any form of direct public intervention. At most, policies aim to guarantee the supply of critical materials.

\section{The PSA-FCA merger}

The merger project between FCA and PSA is a clear example of the total lack of industrial policies in Europe, which leaves the development of such important operations from an industrial and employment point of view completely to market logic. FCA and PSA have announced - before the conclusion of the merger process - a collaboration on a specific model equipped with PSA's CMP (Common Modular Platform). However, it is plausible to believe that the collaboration between the two companies is at an extremely advanced stage and involves most of the components, even those not directly related to the new floorpan adopted.

It is no coincidence that, recently, the two companies announced that the savings deriving from the synergies of the merger have increased from 3.7 to over 5 billion: this means that the collaboration is not limited only to the flatbed, but also involves the rest of the components. The collaboration, in fact, concerns three new B segment vehicles: a "junior" Jeep, an heir of old FIAT Punto (probably under the "500" brand), and an heir of Alfa Romeo Mito.

The plant identified for vehicle production is that of Tychy, in Poland: this is a major decision from an industrial and employment point of view. At stake, in the B segment, there are a total of 5 models, all of which will be produced with PSA's CMP platform. These 5 models, currently unnamed, are:

- A new version of Jeep;

- A new version of Alfa Romeo Mito,

- A new version of Fiat Punto,

- A new version of Lancia Y,

- A new version of Fiat Panda.

The production capacity of the Tychy plant may be insufficient, but it is worth recalling that there is an Opel plant (part of the PSA group) in Gliwice that is certainly already prepared to produce cars with 
PSA platform.

\section{Architecture of models}

The architecture chosen for these vehicles includes the use of PSA's CMP, a newly designed platform which, like all modern platforms, has a modular design, i.e. with a few targeted modifications it can be used to produce a wide range of models. The three FCA floors in Europe are the Small (Panda, 500, Ypsilon and, with some variations, $500 \mathrm{BEV}$ ), US Wide (still used on the only new project that is progressing in Europe, the Alfa Romeo "Tonale") and Ducato. Other "minor" floorpans (e.g. 500L, derived from Punto) seem to have no future even for reaching "age limits". The fact that PSA has imposed its own floorpan will have a very strong impact on the supply of all components. In essence, PSA will choose the solutions to adopt in the mechanical, electronic and powertrain parts as well.

FCA could therefore only keep a role in product development (understood as the integration of the various components chosen by PSA and the design of the internal and external style), without any certainty about plants, where they will be built, and the corresponding suppliers who will be chosen.

Note that adopting a PSA electronic architecture could have a big impact also on FCA after sales (e.g. dealers networks), leading to significant investments in terms of new specific tools and training.

\section{Batteries and Powertrain}

If the relationship between the two companies, which are still separate at the moment, is not clarified in time, FCA risks being overwhelmed in terms of powertrain choices. For example, we know that PSA, Total and SAFT have signed an agreement to create a Joint Venture (ACC) to build two large plants (one in France and one in Germany) to produce batteries for EV and that they will presumably opt for a battery made up of several modules, which is therefore easy to manage and flexible.

PSA has also set up a joint venture with Punchpowertrain, which produces electric motors for hybrid models (MHEV). Punch Powertrain is a Chinese company (acquired 100\% in 2016 by the Yinyi Group, as a subsidiary of the DAF in the 1970s, later passed through Volvo and ZF) specializing in the production of powertrain solutions in hybrid, electric, transmission, etc. The PSA engine has a double camshaft with 4 valves/cylinders, while the FCA engine has a single camshaft with 2 valves/cylinders; it has an oil drive belt instead of FCA's chain; a double thermostat (FCA has only one); and, unlike FCA, does not adopt the EGR (exhaust gas recirculation) system. It is a higher performing, less heavy and less expensive engine: as explained above, it is reasonable to think that PSA can act on the complexity reduction lever to try to impose its solutions on FCA. This PSA engine, therefore, could completely overwhelm the FCA "Firefly" (aka GSE) family, even if those are newly designed brands.

It is clear that if this were the solution adopted, the production of these engines would most likely be located in a PSA Group plant, with serious consequences for the Italian industrial fabric - especially if we consider that there is a concern that the PSA engines that will equip FCA cars could be also produced in Poland (Bielsko Biala). These concerns have a background: FCA hybrid vehicles such as the 500, Panda and Ypsilon mini-Hybrid are equipped with a BSG (Belt Start Generator) engine (Firefly family). In theory, this engine was supposed to be produced in Bielsko-Biala (not far from Tychy, where two of the three models are bodied). Unspecified "quality problems" prevented production from starting in Bielsko-Biala and the engines currently fitted on the three models come from Pernambuco (Brazil).

\section{Parts and Components}


The choice of components weighs on the choice of the PSA platform; as said, it is the same platform with applied version of DS3 Crossback that could be adopted with very few differences between the three types of motorization (endothermic, Mild-Hybrid and "pure" electric). In this sense PSA seems to have acted to reduce complexity (complexity reduction): based on the engineering of the car, in fact, the underbody and the chassis could be the same on all three drive systems, limiting modifications only to the BEV steering system and the battery architecture.

With a platform of PSA origin and with the investments and developments, again by PSA, in the powertrain sector, all the components of future models could be decided by the French carmaker, with the exclusion of FCA, which could be entitled only to re-tuning some chassis components whose hardware is PSA.

In the case of the electric model, both hybrid and BEV, things could be even worse for FCA: who will decide on the adoption of battery packs, electric motor, inverter, gearbox, cable system, battery heating/cooling system, motor control unit, etc.? The same concerns could also affect electronics: infotainment, connectivity, electronic components (movement buttons, electronic handbrake, video cameras, high voltage wiring, etc.).

The choice of electronic components could be imposed by PSA, as it has retained Faurecia, the components company $46 \%$ controlled by PSA. Faurecia, in fact, as a supplier of components, specializes in interior parts (instrument panels, door panels and center consoles, acoustic systems, interior decoration and lighting, interior modules), clean mobility (fuel-saving technologies for ICE and hybrid vehicles, zero emission technologies for fuel cell and battery electric vehicles), and complete

seat parts. In addition, through Faurecia, Clarion Electronics is a supplier of software and electronics (thanks to Clarion, Parrot Automotive and Coagent Electronics, as well as other acquisitions such as CovaTech and Creo Dynamics), cockpit electronic systems integration and advanced driver assistance systems (ADAS).

In this case too, the pieces of the puzzle find their place: it is no coincidence that Faurecia was involved in the merger process with the distribution of shares to the new shareholders in the amount of $23 \%$ to each (which together determines $46 \%$ of PSA).

\section{What about Italian suppliers?}

The answer is simple: for those who already supply parts and components for PSA there will still be space, but for those whose production is mainly aimed at FCA there is a risk of disappearance. Here is the reason for the letter sent in the summer by Manley (but probably written under PSA dictation) to the suppliers through which he communicated the following: "Dear supplier, we would like to inform your company, on behalf of FCA Italy and FCA Poland, that the Fiat Chrysler segment B platform project has been interrupted due to an ongoing technological change. We therefore ask you to stop all research, development and production activities immediately in order to avoid further costs and expenses." At the time of transmission of that letter, it was clear to FCA top management that the change in components would not only affect the platform, but also other parts.

\section{Electrification in FCA}

First of all, we have to ask ourselves: what will happen to the electric 500? Its fate is probably linked to the hybrid model ("Firefly" BSG, same as 500, Panda and Ypsilon - see above) of the 500BEV that FCA could allocate on the same line as the $500 \mathrm{BEV}$ at Mirafiori plant. The production capacity of this production line (declared in 80,000 vehicles per year with a hypothesis of 18 shifts per week) might not be able to accommodate both productions, and presumably the volume of the electric would be fade in favor of the hybrid model. Still, on the subject of electrics, it should be remembered that the Italian 
plant is limited to the final assembly of the car, as the batteries for the electric 500 are currently supplied by Samsung (SDI), whose plant is in Eastern Europe (Hungary) and the hub in Austria.

At the moment, in addition to the 500, the electrification of FCA concerns:

- Jeep: Renegade and Compass, PHEV hybrid models;

- Alfa: the Tonale will be launched as a PHEV hybrid in a year's time, while the BEV is not planned; Stelvio is mature as a hybrid and should therefore proceed; a Giulia hybrid has just been announced for next year.

- LCV (Light Commercial Vehicle) is planned as BEV in the project with San Marco (currently assembled in Costruzioni Sperimentali, but with problems that even threaten the continuation of the project);

- The batteries for Renegade and Compass, hybrid models with PHEV technology, are supplied by the Korean company LG Chem;

- For the future Pro-Master BEV model (dedicated to the US market with RAM brand), the supplier should be the Chinese company CATL;

- For the Tonale PHEV (Alfa Romeo) US version there is a reliable study that envisages switching from the batteries supplied by LG Chem to those of the Chinese CATL.

The US Center of Competence also depends on FCA's electrification strategy: this has made things even more complicated because from the US side the interest in electric cars decreased during the last four years due to well known political reasons. Actually, they are developing the hybridization of Wrangler and other large vehicles.

FCA's strategies on the electric car, which are already suffering from a lack of foresight, little courage and inadequate investment, are increasingly residual, especially in light of PSA's dynamism. At most, FCA could be reduced to being the actuator of electric car strategies developed by PSA.

\section{Industrial policy challenges: which plan for the future?}

As it is all too clear, transformations in the automotive industry pose many challenges. International division of labor within GVCs implies flows of intermediate goods that cross many national borders and therefore generate employment in as many countries. This means that any geographical recomposition of the structure of these chains generates a redistribution of employment between the areas involved. Automotive chains have already strongly changed their geographical composition in recent years. Eastern EU countries, which previously supplied labor-intensive components to German car manufacturers, have over time specialized in the production of less labor-intensive, automotivespecific modules with a high technological content.

At the same time, their basic industries (metals, chemicals, plastic, rubber, etc.) have reduced their importance. In this change of role, they have turned to their periphery, for example Turkey, to obtain the less technological components that they previously used to produce themselves. In turn, Turkey has passed on to countries on its own periphery, such as India, the role of providing basic production for the automotive industry - for example textiles, rubber, plastics, etc.

The network is organized in concentric circles, with their center in Germany. Let us stress that geographical proximity becomes important within just-in-time and just-in-sequence business models, and the development of this GVC exactly deployed following this logic, in particular thanks to Industry 4.0 technologies. 
Table 1 clarified the relevance, in terms of employment, of this GVC - people directly employed in the automotive industry, to which we must add those working in the GVC itself. Electrification is a big problem since, as explained in detail above, the components needed for the assembly of electric cars are very different from those of traditional cars.

Hybrid models, on the contrary, combine the components needed for both traditional and electric vehicles. Moreover, their environmental performance is comparable to that of fully electric vehicles, with the advantage that they do not depend so much on the widespread presence of recharging stations - remember that European countries are lagging behind in this type of infrastructure.

Looking at OEMs investment projects in view of the policies that the EU has decided to adopt can shed light on some crucial issues. As explained above, batteries are currently mainly produced in Asia. There are announcements from OEMs about the opening of battery production plants in Europe, especially in Germany, Hungary, Poland and France. As far as the production of vehicles is concerned, on the other hand, business plans show that $45 \%$ of this production will take place in China.

EU policies, on the other hand, mainly focus on regulations of vehicles' emissions; public procurement; purchase incentives and tax benefits; provision of charging infrastructure; and the identification of batteries for electric vehicles as one of the strategic value chains to be supported.

These policies seem grossly insufficient. Public procurement does not guarantee that vehicles will be produced, and therefore jobs generated or preserved, in Europe. For any individual country concerned by the reduction in employment, giving priority to national companies is forbidden, since it is considered state aid according to EU law. The only way to avoid this problem is resorting to in-house production through a public company.

Purchase incentives and tax benefits only partially reduce the extremely high price of electric vehicles, as compared to traditional ones. This means that only medium-high income families can afford to buy these cars - and in general, that excludes people working in the production of these cars.

The infrastructure of European countries, as far as charging stations are concerned, is still highly insufficient. Since there is also a problem of electricity production and distribution, we believe that the best solution is, again, to set up a European public company to deal with it.

The decision of which type of vehicle to focus on is therefore strategic. In light of what has been explained in detail in the previous sections and hinted at few lines above, electric cars are probably not the right choice. It is worth stressing that hybrid vehicles have excellent environmental performances and can reduce charging problems. They could therefore comply with environmental regulations and, at the same time, preserve employment.

As far as the environment is concerned, moreover, less polluting cars alone are not enough: sustainable mobility plans are also needed to relieve congestion in cities and reduce traffic - in particular the expansion of public transport. Here, too, we are faced with problems that are broader than those of the individual industry - and often at odds with OEMs' goal of generating profit. Again, direct public intervention is needed to face this kind of systemic problems.

In addition, it should not be forgotten that the flows of intermediate commodities we were talking about earlier are responsible for about $20 \%$ of the emissions associated with the production of vehicles. It 
seems a contradiction, therefore, to speak of a green plan without considering the idea of dismantling the model of productive specialization and implementing a project of de-specialization via planning and direct participation into investments and productive activity. This should be particularly clear now, that we have seen how an exogenous event - the pandemic - can at any time destabilize supply chains, which are becoming more and more fragile.

At this point, with ongoing discussions on the Next Generation EU plan - and European countries preparing investment plans to obtain European money - it is important to examine whether or not EU countries are taking advantage of the momentum to strengthen their automotive industries. 


\section{References}

ACEA. 2020. Automobile Industry Pocket Guide 2020-2021

Blagoeva D., Pavel C., Wittmer, D., Huisman, J., Pasimeni, F. 2019. Materials dependencies for dualuse technologies relevant to Europe's defense sector, EUR 29850 EN, Publications Office of the European Union, Luxembourg.

Cardoso D.S., Fael P. O., Espirito-Santo A. 2019. A review of micro and mild hybrid systems. 6th International Conference on Energy and Environment Research, ICEER 2019, 22-25 July, University of Aveiro, Portugal.

Chan C.C., Bouscayrol A., Chen K. 2010. Electric, Hybrid, and Fuel-Cell Vehicles: Architectures and Modeling, IEEE Transactions on Vehicular Technology, vol. 59, no. 2.

Connell Garcia W., Kizior M., Simons W. 2020. Analysing Automobile Industry Supply Chain, Discussion Paper 134, European Commission - Directorate-General for Economic and Financial Affairs.

Ehsani M., Gao Y., Gay S.E., Emadi A. 2005. Modern Electric, Hybrid Electric, and Fuel Cell Vehicles. Fundamentals, Theory, and Design, USA.

Enang W., Bannister C. 2017. Renewable and Sustainable Energy Reviews, Vol. 74.

European Commission. 2017a. Blueprint for Sectoral Cooperation on Skills - Responding to skills mismatches at sectoral level. A key action of the New Skills Agenda for Europe. Luxembourg.

European Commission. 2017b. GEAR 2030 Strategy 2015-2017 - Comparative analysis of the competitive position of the EU automotive industry and the impact of the introduction of autonomous vehicles.

Gaddi M., Garbellini N. 2019. Automotive and Electric Mobility, GUE/NGL European Parliamentary Group.

Gobierno de Espagna. 2020. Plan del impulso de la cadena de valor de la industria de la automocion.

Gouvernment France. 2020. Plan de soutien à l'automobile - pour un industrie vert et compétitive

Nemry F., Leduc G, Muñoz A. 2009. Plug-in Hybrid and Battery-Electric Vehicles: State of the research and development and comparative analysis of energy and cost efficiency. JRC Technical Notes.

Prajapati K.C., Patel R., Sagar, R. 2014. Hybrid Vehicle: A Study on Technology, International Journal of Engineering Research \& Technology (IJERT), Vol. 3 Issue 12.

Shen C., Shan P, Gao T. 2011. A Comprehensive Overview of Hybrid Electric Vehicles, International Journal of Vehicular Technology.

European Commission. 2018. Staff Working Document, Report on Raw Materials for Battery Applications SWD 245/2 final.

Sharova V., Wolff P., Konersmann B., Ferstl F., Stanek R., Hackmann M.. 2020. Evaluation of LithiumIon Battery Cell Value Chain, Working Paper Forschungsförderung, No. 168, Hans-Böckler-Stiftung, Düsseldorf. 